\title{
Effect of Tumour Promoter Anthralin on Gamma Radiation and 4-nitroquinoline 1-oxide Induced Genotoxicity in Diploid Yeast
}

\author{
K. B. Anjaria and B. S. Rao \\ Radiological Physics and Advisory Division, Bhabha Atomic Research Center \\ Trombay, Mumbai 400 085, Maharashtra, India \\ E-mail:kba@magnum.barc.ernet.in,bsrao@apsara.barc.ernet.in
}

\begin{abstract}
KEYWORDS Anthralin, radiation, 4-Nitroquinoline1-oxide, yeast, recombination, mutation
ABSTRACT The potentiating effect of tumour promoter anthralin on gamma radiation and 4-Nitroquinoline 1oxide (4-NQO) induced gene conversion and back mutation was studied using diploid yeast Saccharomyces cerevisiae D7. Cells were exposed to 20-400 Gy of gamma radiation and plated on media without anthralin or containing 0.05$10 \mathrm{mg} / \mathrm{ml}$ of anthralin. In another set of experiments, cells were treated with $0.15-0.5 \mu \mathrm{M} \mathrm{4-NQO}$ and plated on media without anthralin or containing $0.05-0.5 \mu \mathrm{g} / \mathrm{ml}$ of anthralin. The results indicated that anthralin did not modify gamma radiation induced gene conversion or back mutation. Anthralin, however, was found to enhance 4-NQO induced back mutation but not gene conversion. The enhancement was highest with the lowest concentration of anthralin and it decreased subsequently as anthralin concentration was increased.
\end{abstract}

\section{INTRODUCTION}

Anthralin (dithranol, 1,8-dihydroxy-anthrone) was introduced in 1916 by Galewsky (1916) and Unna (1916). Since then it has become a widely used, safe and highly effective topical remedy for the treatment of chronic plaque psoriasis. Anthralin has also been shown to exhibit potent tumour-promoting activities (Bock and Burns 1963; Segal et al. 1971; Baturay and Trombetta 1988; DiGiovanni et al. 1988)

A number of studies have been carried out to study the potentiating effects of tumour promoters on the genotoxic effects induced by carcinogens in vitro. Trosko et al. (1977) have demonstrated that the well-known tumour promoter 12-O-tetradecanoylphorbal-13-acetate (TPA) enhanced UV-induced mutations in mammalian cells, and chemical carcinogens' induced mutations in Salmonella typhimurium and $\mathrm{CHO}$ cells. TPA also enhanced the frequency of spontaneous and X-ray induced sister chromatid exchanges in mammalian cells (Kinsella and Radman 1978; Ohno 1974).

Kunz et al. (1980b) had designed an experiment with three tumour promoters including anthralin using a diploid strain of yeast Saccharomyces cerevisiae. In this study, cells were treated with UV radiation, which was used as an initiating agent. Three known tumour promoters TPA, iodoacetate and anthralin were added to the growth media in order to study their ability to potentiate UV induced various genetic events in yeast. In this study, anthralin was shown to enhance UV induced aberrant colony formation, back mutation and mitotic crossing over.

Diploid yeast is an eukaryotic model system used to study various genetic end-points like gene conversion (non-reciprocal recombination), back mutation, mitotic crossing over (reciprocal recombination) and aberrant colony formation. Each genetic event is very significant for various detrimental effects observed in human beings, e.g., induction of carcinogenicity, tumour promotion and heritable diseases. Mutation is a very well studied end-point. A high degree of correlation has been observed between carcinogenicity and mutagenicity of chemicals and it is now generally accepted that most of the carcinogens are mutagens (Mc Cann et al. 1975; Mc Cann and Ames 1976; Miller and Miller 1971). Recombination has been suggested to be involved in carcinogenesis and teratogenesis (Zimmermann et al. 1966; Kinsella and Radman 1978; Kunz et al. 1980a,b) and expression of deleterious genes following recombination may also result in heritable changes. Formation of aberrant colonies in yeast can be due to mitotic gene conversion, point mutation, chromosome deletion or aneuploidy induced by a mutagen. It has been suggested that aberrant mitotic segregation events like mitotic recombination, non-disjunction and other 
chromosomal events might be involved in tumour promotion (Kinsella and Radman 1978). These genetic events occurring in eukaryotic model system-diploid yeast are important as similar events may occur in man. Homologous genes controlling recombinational pathways (HsRAD52) have been identified in human cells (Thomson 1996). Homologous genes of RAD52 epistasis group have been identified in fission yeast (Ostermann et al. 1993); Drosophila melanogaster (Akaboshi et al. 1994) chicken (Bezzubova et al. 1993) mouse and human (Shinohara et al. 1993; Morita et al. 1993) which indicate that the recombinational repair pathway is conserved throughout evolution.

In view of the above observations, we decided to study the effect of tumour promoter anthralin on gamma radiation and 4-Nitroquinoline 1-oxide (4-NQO) induced genetic events in yeast.

\section{MATERIALSANDMETHODS}

Strain: Diploid strain of yeast Saccharomyces cerevisiae D7 used for the study was donated by Prof. F. K. Zimmermann (Darmstadt, Germany). The genotype of the strain is as follows. ilv1-92

a/ $\alpha$ ade2-40/ade2-119, trp5-12/trp5-27, ilv1-92/

The end-points detected using this strain are gene conversion (non-reciprocal recombination), back mutation, mitotic crossing over (reciprocal recombination) and aberrant colony formation. The details of the media and procedures have been described elsewhere (Zimmermann, 1973; 1977; Zimmermann et al., 1975; Anjaria and Madhvanath, 1988). Induction of gene conversion is detected as the conversion of tryptophan auxotrophs to prototrophs, which results in the appearance of colonies on tryptophan omission (Trp') medium. Back mutation results in the reversion of isoleucine auxotrophs to prototrophs and is detected by the appearance of colonies on isoleucine omission (ilv') medium.

Gamma Irradiation: The samples were irradiated in the ${ }^{60} \mathrm{Co}$ gamma chamber having a dose rate of $40 \mathrm{~Gy} / \mathrm{min}$. Stationary phase yeast cells were washed and resuspended at a titre of $2 \times 10^{7}$ cells per $\mathrm{ml}$ in potassium phosphate buffer (0.1M, pH 7.0). The suspension was distributed in $5 \mathrm{ml}$ aliquots in irradiation vials, which were exposed to graded doses in the range of 20-100 Gy. The samples were agitated vigorously in a vortex mixture to aerate them properly just before irradiation. They were maintained at $0-4^{\circ} \mathrm{C}$ before and after irradiation till the time of plating to arrest any metabolic activities in the cells. Irradiated cell suspensions were then plated on ilv, Trp and SC media with or without anthralin to score back mutation, gene conversion and survival respectively. Anthralin was dissolved in DMSO and was added to autoclaved media at concentrations of 0.05 and $0.10 \mu \mathrm{g} / \mathrm{ml}$. Colonies were counted after 5 days after incubation at $30^{\circ} \mathrm{C}$.

Further experiments were carried out by increasing the anthralin concentration in the media to $0.15,1.0$ and $10 \mu \mathrm{g} / \mathrm{ml}$. Two radiation doses were used: $100 \mathrm{~Gy}$, which is the highest dose at which cell killing is negligible and $400 \mathrm{~Gy}$ which results in about $40 \%$ survival.

4-NQO Treatment: 4-NQO was purchased from K \& K Laboratories, New York, USA. The stock solution of 4-NQO was freshly prepared in DMSO each time and diluted in potassium phosphate buffer (0.1M, pH 7.0). The cells were washed and resuspended in buffer. Titre of the stock cell suspension was usually $5 \times 10^{7}$ cells $/ \mathrm{ml}$. For the treatment, usually $1 \mathrm{ml}$ of stock cell suspension, required volume of 4-NQO solution and buffer were mixed to get about $20 \mathrm{ml}$ of the reaction mixture. The flasks containing the reaction mixture were incubated in a shaker water bath at $30^{\circ} \mathrm{C}$ in dark. 4-NQO treatments were carried out at $0.15,0.3$ and $0.5 \mu \mathrm{M}$. At the end of $1 \mathrm{~h}$ of treatment, samples were withdrawn, filtered through a Millipore filter (pore size $0.45 \mu \mathrm{M}$ ), washed thrice with buffer and resuspended in buffer to obtain the desired cell concentration. Following appropriate dilutions, one $\mathrm{ml}$ of the cell suspension was spread on 4 plates each of Ilv-, Trp and synthetic complete media plates either without anthralin or containing $0,0.05,0.1$, 0.15 and $0.5 \mu \mathrm{g}$ anthralin per $\mathrm{ml}$ of media to score back mutation, gene conversion and survival respectively. Plates were incubated at $30^{\circ} \mathrm{C}$ and colonies were counted after 5 days.

\section{RESULTS}

Effect of Anthralin on Gamma Radiation Induced Gene Conversion and Back Mutation in Strain D7: Effect of tumour promoter anthralin on gamma radiation induced gene conversion and back mutation is reported in Tables 1 and 2 . Under the treatment conditions used, anthralin neither induced any cell killing per se; nor did it 
enhance radiation induced cell killing. Also, it did not increase spontaneous frequency of gene conversion or back mutation. The results indicate that it had no effect on radiation induced gene conversion or back mutation frequencies. Subsequent experiments were carried out with

Table 1: Effect of low concentrations of anthralin on gamma radiation induced gene conversion

\begin{tabular}{lccc}
\hline $\begin{array}{c}\text { Gamma } \\
\text { dose }(\mathrm{Gy})\end{array}$ & $\begin{array}{c}\text { Anthralin } \\
(\mu \mathrm{g} / \mathrm{ml})\end{array}$ & $\begin{array}{c}\text { Convertants } / 10^{6} \\
\text { survivors }\end{array}\left(\mathrm{C} / 10^{6} \mathrm{~s}\right)$ & $\begin{array}{c}\text { Ratio } \\
\text { of } \mathrm{C} / 10^{6} s \\
R+A / R\end{array}$ \\
\hline 0 & $A$ & $8 \pm 5$ & - \\
20 & - & $97 \pm 11$ & - \\
40 & - & $195 \pm 26$ & - \\
60 & - & $255 \pm 43$ & - \\
80 & - & $314 \pm 47$ & - \\
100 & - & $373 \pm 56$ & - \\
Combined & - & $7 \pm 2$ & $1.01 \pm 0.01$ \\
0 & 0.05 & $103 \pm 7$ & $1.07 \pm 0.05$ \\
20 & 0.05 & $191 \pm 55$ & $0.97 \pm 0.16$ \\
40 & 0.05 & $297 \pm 81$ & $1.06 \pm 0.04$ \\
60 & 0.05 & $369 \pm 82$ & $1.07 \pm 0.03$ \\
80 & 0.05 & $473 \pm 7$ & $1.30 \pm 0.21$ \\
100 & 0.05 & $7 \pm 2$ & $1.01 \pm 0.01$ \\
0 & 0.1 & $116 \pm 1$ & $1.22 \pm 0.14$ \\
20 & 0.1 & $167 \pm 3$ & $0.87 \pm 0.11$ \\
40 & 0.1 & $257 \pm 45$ & $1.01 \pm 0.01$ \\
60 & 0.1 & $332 \pm 39$ & $1.06 \pm 0.04$ \\
80 & 0.1 & $386 \pm 54$ & $1.04 \pm 0.01$ \\
100 & 0.1 & &
\end{tabular}

${ }^{1}$ Values represent mean \pm s.d. of 3 experiments

Table 2: Effect of low concentration of anthralin on gamma radiation induced back mutation

\begin{tabular}{lccc}
\hline Gamma & Anthralin & ${\text { Revertants } / 10^{7}}^{\text {Ratio of }}$ \\
dose $(G y)$ & $(\mu g / m l)$ & survivors $^{l} R / 10^{7} s$ & $R / 10^{7} s$ \\
$R$ & $A$ & & $R+A / R$ \\
\hline
\end{tabular}

\begin{tabular}{lcrc}
\hline 0 & - & $9 \pm 1$ & - \\
20 & - & $52 \pm 1$ & - \\
40 & - & $99 \pm 13$ & - \\
60 & - & $134 \pm 52$ & - \\
80 & - & $172 \pm 54$ & - \\
100 & - & $248 \pm 14$ & - \\
Combined & & $7 \pm 1$ & $0.78 \pm 0.03$ \\
0 & 0.05 & $56 \pm 4$ & $0.94 \pm 0.04$ \\
20 & 0.05 & $107 \pm 15$ & $0.93 \pm 0.01$ \\
40 & 0.05 & $146 \pm 81$ & $0.93 \pm 0.01$ \\
60 & 0.05 & $198 \pm 47$ & $0.80 \pm 0.06$ \\
80 & 0.05 & $248 \pm 7$ & $1.00 \pm 0.03$ \\
100 & 0.05 & $15 \pm 4$ & $1.08 \pm 0.18$ \\
0 & 0.1 & $108 \pm 18$ & $0.93 \pm 0.00$ \\
20 & 0.1 & $139 \pm 47$ & $0.92 \pm 0.04$ \\
40 & 0.1 & $178 \pm 34$ & $0.94 \pm 0.15$ \\
60 & 0.1 & $247 \pm 21$ & $1.01 \pm 0.03$ \\
80 & 0.1 & & \\
100 & 0.1 & & \\
\hline
\end{tabular}

${ }^{1}$ Values represent mean \pm s.d. of 3 experiments higher concentrations of anthralin. The results shown in Tables 3 and 4 indicate that anthralin even when used at higher concentrations in combination with higher radiation doses, did not modify radiation-induced genotoxicity.

Effect of Anthralin on 4-NQO Induced Gene Conversion and Back Mutation in Strain D7: In experiments carried out with 4-NQO, anthralin had no effect on cell survival following 4-NQO treatments. Further, the results show that anthralin at $0.05-0.5 \mu \mathrm{g} / \mathrm{ml}$ had no effect on 4-NQO induced gene conversion frequency at all the 3 concentrations of 4-NQO (Table 5).

However, the back mutation frequency induced by $0.15,0.3$ and $0.5 \mu \mathrm{M} 4-\mathrm{NQO}$ was found to increase in the presence of anthralin (Table 6). The increase was consistently seen for the lowest concentration of anthralin $(0.05 \mu \mathrm{g} / \mathrm{ml})$ for all the 3 concentrations of 4-NQO: For $0.15 \mu \mathrm{M} 4-$ NQO, anthralin increased the back mutation frequency by $29 \%$ ( $\mathrm{p}<0.0027$ ), for $0.3 \mu \mathrm{M} 4-\mathrm{NQO}$, it increased by $57 \%(\mathrm{p}<0.05)$ and for $0.5 \mu \mathrm{M} 4-$ NQO it increased by $34 \%$ ( $\mathrm{p}<0.0027)$.

For 0.3 and $0.5 \mu \mathrm{M} 4-\mathrm{NQO}$, the increase was seen even with $0.10 \mathrm{mg} / \mathrm{ml}$ anthralin: For $0.3 \mu \mathrm{M}$ 4-NQO, the increase was $20 \%$ ( $\mathrm{p}<0.0027)$ and for $0.5 \mu \mathrm{M} 4-\mathrm{NQO}$, the increase was $14 \%(\mathrm{p}<0.05)$.

However, the enhancement in back mutation frequency was maximum for the lowest concentration i.e., $0.05 \mu \mathrm{g} / \mathrm{ml}$ of anthralin. As the concentration of anthralin in the growth medium was increased, the enhancement diminished and was absent when higher anthralin concentrations were used. This pattern was most clearly seen for $0.5 \mu \mathrm{M}$ of $4-\mathrm{NQO}$.

\section{DISCUSSION}

In our study, the tumour promoter anthralin did not modify gamma radiation induced gene conversion and back mutation frequency. In experiments carried out with 4-NQO, anthralin did not alter 4-NQO induced gene conversion frequency but increased the induced back mutation frequency.

The molecular basis of promotion and cocarcinogenesis are not clearly understood. It is assumed that many tumour mutations are recessive (Gateff 1978; Harris et al. 1968; Stanbridge 1976) and hence they will not be expressed if present as single copies in normal diploid cells. The potentiation of mutagenic and recombinagenic effects of carcinogens by various mechanisms could also result in enhanced 
Table 3: Effect of higher concentration of anthralin on gamma radiation induced gene conversion

\begin{tabular}{lccc}
\hline $\begin{array}{c}\text { Gamma } \\
\text { dose }(\mathrm{Gy})\end{array}$ & $\begin{array}{c}\text { Anthralin } \\
(\mu \mathrm{g} / \mathrm{ml})\end{array}$ & $\begin{array}{c}\text { Convertants/ } \\
10^{6} \mathrm{~s}^{1} \\
\mathrm{C} / 10^{6} \mathrm{~s}\end{array}$ & $\begin{array}{c}\text { Ratio } \\
\text { of C/10 } \\
R+A / R\end{array}$ \\
\hline 0 & $\mathrm{~A}$ & $10 \pm 2$ & - \\
& - & $11 \pm 3$ & - \\
& 0.15 & $10 \pm 1$ & - \\
100 & 1.0 & $10 \pm 2$ & - \\
$(90 \%$ survival $)$ & - & $579 \pm 21$ & - \\
& 1.0 & $528 \pm 55$ & $1.08 \pm 0.15$ \\
400 & 10.0 & $563 \pm 48$ & $0.89 \pm 0.14$ \\
$(40 \%$ survival $)$ & - & $2774 \pm 293$ & $0.95 \pm 0.11$ \\
& 0.15 & $2814 \pm 472$ & $0.91 \pm 0.07$ \\
& 1.0 & $2797 \pm 130$ & $1.09 \pm 0.09$ \\
& 10.0 & $2619 \pm 33$ & $0.99 \pm 0.07$ \\
\hline
\end{tabular}

${ }^{1}$ Values represent mean \pm s.d. of 2 experiments

Table 4: Effect of higher concentration of anthralin on gamma radiation induced back mutation

\begin{tabular}{lccc}
\hline $\begin{array}{c}\text { Gamma } \\
\text { dose }(\mathrm{Gy})\end{array}$ & $\begin{array}{c}\text { Anthralin } \\
(\mu \mathrm{g} / \mathrm{ml})\end{array}$ & $\begin{array}{c}\text { Revertants/ } \\
10^{7} \mathrm{~s}^{1} \\
R / 10^{7} \mathrm{~s}\end{array}$ & $\begin{array}{c}\text { Ratio of } \\
\text { Rev/10 } \\
R+A / R\end{array}$ \\
\hline 0 & $A$ & $10 \pm 5$ & - \\
- & - & $4 \pm 3$ & - \\
- & 0.15 & $5 \pm 3$ & - \\
- & 1.0 & $10 \pm 3$ & - \\
100 & 10 & $289 \pm 37$ & - \\
$(90 \%$ survival $)$ & 0.15 & $330 \pm 89$ & $1.05 \pm 0.03$ \\
& 1.0 & $242 \pm 46$ & $1.02 \pm 0.05$ \\
400 & 10.0 & $349 \pm 88$ & $1.10 \pm 0.01$ \\
$(40 \%$ survival $)$ & 0.15 & $1658 \pm 147$ & - \\
& 1.0 & $1565 \pm 149$ & $0.88 \pm 0.16$ \\
& 10.0 & $1596 \pm 69$ & $0.99 \pm 0.01$ \\
\hline
\end{tabular}

${ }^{1}$ Values represent mean \pm s.d. of 2 experiments

fixation and expression of tumour mutations and thus might play a role in cocarcinogenesis.

A large body of evidence has shown that the biochemical basis for the mechanism of action of anthralin at molecular level is related to its redox activity leading to the production of active oxygen species, which includes singlet oxygen, superoxide anion radical and hydroxyl radical (Mueller and Huang 1996). It has been reported that antioxidants were effective inhibitors of anthrone tumour promotion, indicating an important role of oxygen radicals in the mechanism of action of this class of tumour promoters. (Battalora et al. 1993). These active oxygen species generated by anthralin can react with all classes of biological macromolecules and are responsible for all principal cellular effects, viz.,
Table 5: Effect of anthralin on 4-NQO induced gene conversion in strain D7

\begin{tabular}{|c|c|c|c|c|}
\hline $\begin{array}{l}4-N Q O \\
(\mu M) \\
N \\
\end{array}$ & $\begin{array}{c}\text { Anthralin } \\
(\mu \mathrm{g} / \mathrm{ml}) \\
A\end{array}$ & $\begin{array}{c}\text { Convertants } / 10 \\
\text { survivors } \\
\left(C / 10^{6} s\right)^{1}\end{array}$ & & $\begin{array}{c}\text { Ratio of } \\
C / 10^{6} \mathrm{~s} \\
N+A / N \\
\end{array}$ \\
\hline - & - & $12 \pm 5$ & & - \\
\hline - & 0.05 & $12 \pm 3$ & & - \\
\hline - & 0.10 & $15 \pm 6$ & & - \\
\hline - & 0.15 & $13 \pm 5$ & & - \\
\hline - & 0.50 & $9 \pm 3$ & & - \\
\hline 0.15 & - & $73 \pm 8$ & & - \\
\hline 0.15 & 0.05 & $72 \pm 13$ & $0.98=$ & \pm 0.09 \\
\hline 0.15 & 0.10 & $69 \pm 12$ & $0.94=$ & \pm 0.08 \\
\hline 0.15 & 0.15 & $75 \pm 15$ & $1.03=$ & \pm 0.19 \\
\hline 0.15 & 0.50 & $80 \pm 16$ & $1.10=$ & \pm 0.15 \\
\hline 0.30 & - & $153 \pm 1$ & & - \\
\hline 0.30 & 0.05 & $144 \pm 8$ & $0.95=$ & \pm 0.06 \\
\hline 0.30 & 0.10 & $164 \pm 4$ & $1.08=$ & \pm 0.03 \\
\hline 0.30 & 0.15 & $186 \pm 3$ & $1.22=$ & \pm 0.02 \\
\hline 0.30 & 0.50 & $152 \pm 12$ & $1.00=$ & \pm 0.08 \\
\hline 0.50 & - & $340 \pm 104$ & & - \\
\hline 0.50 & 0.05 & $326 \pm 79$ & $0.98=$ & \pm 0.07 \\
\hline 0.50 & 0.10 & $401 \pm 77$ & $1.23=$ & \pm 0.15 \\
\hline 0.50 & 0.15 & $339 \pm 104$ & $1.00=$ & \pm 0.00 \\
\hline 0.50 & 0.50 & $378 \pm 133$ & $1.10=$ & \pm 0.06 \\
\hline
\end{tabular}

${ }^{1}$ Values represent mean \pm s.d. of 2-3 experiments

Table 6: Effect of anthralin on 4-NQO induced back mutation in strain $\mathrm{D} 7$

\begin{tabular}{lccc}
\hline $\begin{array}{l}4-N Q O \\
(\mu M)\end{array}$ & $\begin{array}{c}\text { Anthralin } \\
(\mu g / m l)\end{array}$ & $\begin{array}{c}\text { Revertants } / 10^{7} \\
\text { survivors } \\
\left(R / 10^{7}\right)^{1}\end{array}$ & $\begin{array}{c}\text { Ratio of } \\
R / 10^{7} s \\
N+A / N\end{array}$ \\
\hline & - & $8 \pm 3$ & - \\
- & - & $14 \pm 7$ & - \\
- & 0.05 & $14 \pm 6$ & - \\
- & 0.1 & $15 \pm 7$ & - \\
- & 0.15 & $11 \pm 5$ & - \\
- & 0.5 & $136 \pm 37$ & - \\
0.15 & - & $174 \pm 41$ & $1.29 \pm 0.045^{\mathrm{a}}$ \\
0.15 & 0.05 & $127 \pm 5$ & $0.99 \pm 0.23$ \\
0.15 & 0.1 & $163 \pm 63$ & $1.15 \pm 0.15$ \\
0.15 & 0.15 & $136 \pm 34$ & $1.00 \pm 0.025$ \\
0.15 & 0.5 & $232 \pm 2$ & - \\
0.3 & - & $364 \pm 53$ & $1.57 \pm 0.22^{\mathrm{b}}$ \\
0.3 & 0.05 & $277 \pm 3$ & $1.20 \pm 0.03^{\mathrm{a}}$ \\
0.3 & 0.1 & $253 \pm 26$ & $1.09 \pm 0.10$ \\
0.3 & 0.15 & $311 \pm 29$ & $1.35 \pm 0.14^{\mathrm{b}}$ \\
0.3 & 0.5 & $274 \pm 69$ & - \\
0.5 & - & $370 \pm 100$ & $1.34 \pm 0.02^{\mathrm{a}}$ \\
0.5 & 0.05 & $310 \pm 71$ & $1.14 \pm 0.025^{\mathrm{b}}$ \\
0.5 & 0.1 & $298 \pm 58$ & $1.10 \pm 0.07$ \\
0.5 & 0.15 & $264 \pm 39$ & $0.99 \pm 0.11$ \\
0.5 & 0.5 &
\end{tabular}

${ }^{1}$ Values represent mean \pm s.d. of 2-4 experiments. a $\mathrm{p}<0.0027$

$\mathrm{b} \mathrm{p}<0.05$

interaction with DNA, modification of bases, inhibition of all enzyme systems involved in metabolic pathways and cellular respiration; and also destruction of membrane lipids (Mueller and 
Huang 1996). Birnboim (1986) has shown that anthralin induces DNA strand breaks and suggested that the slow repair of DNA strand breaks may be significant in the mechanism of action of tumour promoting agent like anthralin. The induction of DNA strand breaks (Birnboim 1986) and inhibition of DNA replication (Clark and Hanawalt 1982) by anthralin is suggested to be due to the formation of modified DNA bases. Kulkarni and Yielding (1978) have indicated that anthralin causes accumulation of repair intermediates which could act as inducers of error-prone repair pathways. The property of anthralin to inhibit DNA synthesis and repair replication is suggested to be consistent with the ability of any agent to induce mutation and recombination; and/or to enhance genetic events induced by other DNA damaging agents (Kunz et al. 1980b; Clark and Hanawalt 1982). Anthralin has been shown to potentiate UV induced genetic events like mutation, aberrant colony formation and crossing over in yeast (Kunz et al. 1980b). In our study, it did not enhance gamma radiation induced gene conversion and back mutation frequency but enhanced 4-NQO induced back mutation frequency. 4-NQO is a UV-mimetic agent and mimics the action of UV rays in certain ways (Kondo 1981). Moreover, it has been shown that most of the 4-NQO-induced DNA lesions in vivo are 4-NQO-purine adducts, which are repaired by the same excision repair system that is effective for UV-induced pyrimidine dimers (Kondo 1981) and also that the repair of 4-NQO and UV damage is of the long patch type (Regan and Setlow 1974; Stich and San 1971; Cleaver 1973). However, the repair processes operating on the UV induced damage may differ in some other ways from those operating on the 4-NQO induced damage (Ahmed and Setlow 1980). From our results, it appears that anthralin specifically enhances the genetic effects induced by UV (Kunz et al. 1980) and UV-mimetic agent 4-NQO (our data) but not by gamma radiation. Similarly, selective enhancement of neoplastic transformation by anthralin was observed with $\mathrm{B}(\mathrm{a}) \mathrm{P}$ but not with $\beta$-propiolactone (Baturay and Trombetta 1988). However, very little information is available in literature regarding the modifying effects of anthralin for a wide variety of DNA damaging agents having different mechanisms of action.

A notable feature in this study is the dose related decrease in the potentiation of $4-\mathrm{NQO}$ induced back mutation frequency by anthralin. Similar decline in the potentiating effect of other tumour promoters was reported by Kunz et al. (1980b) e.g. the potentiation of UV-induced aberrant colonies declined with increasing concentration of TPA. Also, potentiation of UVinduced gene conversion frequency decreased with increasing concentration of tumour promoter catechol. Similarly, potentiation of UV induced mitotic crossing over decreased with increasing concentration of tumour promoter iodoacetate. Hannan et al. (1980) have also reported such a reduction while studying the potentiation involving UV induced mutation and mitotic recombination by tobacco smoke condensate. The reason for this effect has not been understood.

In conclusion, anthralin did not modify gamma radiation induced gene conversion and back mutation frequency in yeast. It potentiated 4-NQO-induced back mutation frequency but not gene conversion frequency. The potentiation was highest with lowest concentration of anthralin and it decreased with the increase in the concentration of anthralin.

\section{REFERENCES}

Ahmed FE, Setlow RH 1980. DNA excision in repair proficient and deficient Human cells treated with a combination of ultraviolet radiation and acridine mustard (ICR-170) or 4-Nitroquinoline 1-oxide. Chem Biol Interactions, 29: 31-42.

Akaboshi E, Inoue Y, Ryo H 1994. Cloning of the cDNA and genomic DNA that correspond to the recAlike gene of Drosophila melanogaster. Japanese $J$ Genet, 69: 663-670.

Anjaria KB, Madhvanath U 1988. Genotoxicity of selenite in diploid yeast. Mutat Res, 204: 605-614.

Battalora MSJ, Kruszewski FH, DiGiovanni J 1993. Inhibition of chrysarobin skin tumour promotion in SENCAR mice by antioxidants. Carcinogenesis, 14: $2507-2512$.

Baturay NZ, Trombetta LD 1988. Cocarcinogenic and tumour promoting capabilities of anthralin. Arch Dermatol Res, 280: 443-450.

Bezzubova O, Schmidt H, Ostermann K, Heder WD, Buerstedde JM 1993. Identification of a chicken RAD52 homologue suggests conservation of the RAD52 recombination pathway throughout the evolution of higher eukaryotes. Nucleic Acid Res, 21: 5945-5949.

Birnboim HC 1986. DNA strand breaks in human leukocytes induced by superoxide anion, hydrogen peroxide and tumour promoters are repaired slowly compared to breaks induced by ionizing radiation. Carcinogenesis UK, 7: 1511-1517.

Bock FG, Burns K 1963. Tumor promoting properties of anthralin (1,8,9-anthratriol). J National Cancer Inst, 30: 393-398. 
Clark JM, Hanawalt PC 1982. Inhibition of DNA replication and repair by anthralin or danthron in cultured human cells. J Invest Dermatol USA, 79: 18-22.

Cleaver JE 1973. DNA repairs in purines and pyrimidines in radiation- and carcinogen-damaged normal and Xeroderma pigmentosum human cells. Cancer Res, 33: $362-369$.

DiGiovanni J, Kruszewski FH, Coombs MM, Bhatt TS, Pezeshk A 1988.Structure activity relationships for epidermal ornithine decarboxylase induction and skin tumour promotion by anthrones. Carcinogenesis, 9: 1437-1443.

Galewsky U 1916. Über Cignolin, ein Ersatzpräparat des Chrysarobins. Dermatolo. Wochenschenschr, 62: 113-115.

Gateff E 1978. Malignant neoplasms of genetic origin in Drosophila melanogaster, Science (Wash. D.C.), 200: $1448-1459$

Hannan MA, Estes RS, Hurley L 1980. Induction \& potentiation of lethal and genetic effects of ultraviolet light by tobacco smoke condensates in yeast. Env Res, 21: 97-107.

Harris H, Miller OJ, Klein G, Worst P, Tachibana T 1968. Suppression of malignancy by cell fusion. Nature (Lond.), 223: 363-368

Kinsella A, Radman M 1978. Tumor promoter induces sister chromatid exchanges; Relevance to mechanisms of carcinogenesis. Proc Natl Acad Sci USA, 75: 6149-6158.

Kondo S 1981. Molecular biology of 4-Nitroquinoline 1-oxide in the prokaryotic system. In: Sugimura T (Ed.): Carcinogenesis. The Nitroquinolines. New York: Raven Press pp.47-64.

Kulkarni MS, Yielding KL 1978. Inhibition of UV-induced DNA repair at different steps by quinacrine and anthralin. Biochem Biophys Res Commun, 83: 1531-1537.

Kunz BA, Barclay BJ, Haynes RH 1980a. A simple rapid, plate assay for mitotic recombination. Mutat Res, 73: $215-220$

Kunz BA, Hannan MA, Haynes RH 1980b. Effect of tumor promoters on Ultraviolet light-induced mutation and mitotic recombination in Saccharomyces cerevisiae. Cancer Res, 40: 23232329.

Morita T, Yoshimura Y, Yamamoto A, Murata K, Mori M, Yamamoto H, Matsushiro 1993. A mouse homolog of the Escherichia coli recA and Saccharomyces cerevisiae Rad51 genes. Proc Natl Acad Sci USA, 90: 6577-6580.

Mueller-K, Huang HS 1996. Development of novel antipsoriatic anthrones. Chinese Pharmaceutical $J$, 48: 337-354.
Ohno S 1974. Aneuploidy as a possible means employed by malignant cells to express recessive phenotypes. In: J. German (Ed.): Chromosomes and Cancer. pp. $77-94$

Ostermann K, Lorentz A, Schmidt H 1993. The fission yeast rad22 gene, having a function in switching and repair of DNA damages, encodes a protein homolog to Rad52 of Saccharomyces cerevisiae. Nucleic Acids Res, 21: 5940-5944.

Regan JD, Setlow RB 1974. Two forms of repair in the DNA of human cells damaged by chemical carcinogens and mutagens. Cancer Res, 34: 33183325 .

Segal A, Katz C, Van Duuren BL 1971. Structure and tumour promoting activity of anthralin (1,8dihydroxy-9-anthrone) and related compounds. $J$ Med Chem, 14: 1152-1154.

Shinohara A, Ogawa H, Matsuda Y, Ushio N, Ikeo K, Ogawa T 1993. Cloning of human, mouse and fission yeast recombination genes homologous to RAD51 and recA. Natural Genetics, 4: 239-243.

Stanbridge EJ 1976. Suppression of malignancy in human cells. Nature (Lond.), 260: 17-20.

Stich HF, San RHC 1971. Reduced DNA repair synthesis in xeroderma pigmentosum cells exposed to the oncogenic 4-Nitroquinoline 1-oxide and 4Hydroxyaminoquinoline 1-oxide. Mutat Res, 13: 279-333.

Thomson LH 1996. Evidence that mammalian cells possess homologous recombinational repair pathways. Mutat Res, 363: 77-88.

Trosko JE, Chang C, Yotti LP, Chu EHY 1977. Effect of phorbol myristate acetate on the recovery of spontaneous and ultraviolet light-induced 6thioguanine and oubain-resistant Chinese hamster cells. Cancer Res, 37: 188-193.

Unna PG 1916. Cignolin als Heilmittel der Psoriasis. Dermatolo Wochenschr, 62: 116-137.

Zimmermann FK 1973. A yeast strain for visual screening for the two reciprocal products of mitotic crossing over. Mutat Res, 21: 263-269.

Zimmermann FK 1977. Procedures used in the induction of mitotic recombination and mutation in the yeast Saccharomyces cerevisiae.In: Kilbey et al. (Ed.): Handbook of Mutagenicity Test Procedures. Elsevier: North-Holland Biomedical Press pp.119-134.

Zimmermann FK, Kern R, Rasenberger HA 1975. A yeast strain for simultaneous detection of induced mitotic crossing over, mitotic gene conversion, and reverse mutation. Mutat Res, 28: 381-388.

Zimmermann FK, Schwaier R, v Laer U 1966. Mitotic recombination induced in Saccharomyces cerevisiae with nitrous acid, diethyl sulfate and carcinogenic nitrosamides. Z Vereebungsl, 98: 230-246. 